\title{
Pyrazole derivatives efficient organic inhibitors for corrosion in aggressive media: A comprehensive review
}

\author{
I. Merimi, R. Touzani, A. Aouniti, A. Chetouani and B. Hammouti*io \\ University Mohamed Premier, Faculty of Sciences, Department of Chemistry, Laboratory \\ of Applied and Environmental Chemistry, BV Mohammed VI, BP 524, 60000 Oujda, \\ Morocco \\ *E-mail: hammoutib@gmail.com
}

\begin{abstract}
The high cost of corrosion estimated by billions of dollars per a year for industries. The research of new inhibitors to stop the increase of this phenomenon is more appreciate and tolerated during metallic materials use by human kind. Research of organic as well as mineral inhibitors increases more and more to stop or retard destruction of metals in aggressive media. Since 1995, our laboratory research had given an important thinking to solve this problem by using various techniques as weight loss, potentiodynamic and polarization resistance measurements. The focus was in using an organic inhibitor containing heteroatoms such as azoles derivatives, pyrazine; thiophene as well as extracts or oil of natural plants, etc. In this review, we report our contribution to this field by using pyrazole and bipyrazole derivatives as efficient and good inhibitors against corrosion in acidic media. Inhibitory effect depends on the constituent groups, metallic materials, corrosive medium. Pyrazole and bipyrazole compounds adsorb on the metallic surface according to physical and/or chemical process, and can also form organic-metal ion complexes. Marvinsketch.18 program was used in order to detect predominant form of inhibitors in electrolytic solution and then computed by Gaussian 09 based on the DFT method at B3LYP/6-31G(d,p) to correlate results obtained theoretically with those obtained experimentally.
\end{abstract}

Keywords: pyrazole; organic inhibitors; inhibition; corrosion; acidic media; $\mathrm{NaCl}$.

Received: May 27, 2020. Published: October 7, 2020

doi: $\underline{10.17675 / 2305-6894-2020-9-4-4}$

\section{Introduction}

Pyrazoles and bipyrazoles have attracted interest as ligands owing to the versatility of their coordination behavior towards a great variety of metals. Pyrazoles and bipyrazoles are regarded as one of the most flexible ligand systems in coordination chemistry due to their ease of synthesis and tunability of the substituents. These remarkable properties allowed to these materials a huge amount of applications. These lists are not exhaustive, for example, the pyrazole ligand was incorporated for preparing a novel advanced material for luminescent MOF compounds with specific engineering and design [1-6]. They presented also some biological activities such as modulators of CDK, GSK, aurora kinases and CCR1 
antagonists [7-11]. They are useful in the treatment of diabetes and syndrome $\mathrm{X}$ and they are effective against renal disease [12-16]. They were also tested as herbicides in agrochemical components to 16 kinds of grasses [17-19]. The transport and extraction of $\mathrm{Cd}(\mathrm{II}), \mathrm{Pb}(\mathrm{II})$, and $\mathrm{Hg}(\mathrm{II})$ were also investigated using the pyrazole moieties [20-22]. They are the subject of many inventions related to use as contrast agents in imaging diagnosis [23-24]. These nitrogen compounds gain a lot of application in corrosion as a good organic inhibitor du the presence of the labile electron doublet on the nitrogen. Accordingly, we now report a comprehensive review about pyrazole, bipyrazole and derivatives with the emphasize on their uses as good and an excellent organic inhibitor for corrosion in different media $\mathrm{HCl}, \mathrm{H}_{2} \mathrm{SO}_{4}, \mathrm{H}_{3} \mathrm{PO}_{4}, \mathrm{HNO}_{3}$ and $\mathrm{NaCl}$.

\section{Inhibition of corrosion by pyrazole derivatives in $\mathrm{HCl}$ media}

Four industrially relevant pyrazole derivatives (1-4) differing in their nature of substituents were synthesized and their acid corrosion inhibition was studied for mild steel using experimental and computational approaches. Results revealed that the inhibition capability of these pyrazoles was substituent-and concentration-dependent. The inhibition efficiency followed the order: $\mathbf{4}(94.88 \%)>\mathbf{3}(91.47 \%)>\mathbf{2}(90.90 \%)>\mathbf{1}(89.77 \%) . \quad$ By electrochemical studies these materials acted as mixed-type inhibitors and their adsorption obeyed the Langmuir isotherm. The DFT and MD simulations, and correlated with the experimental results [25] (Figure 1).

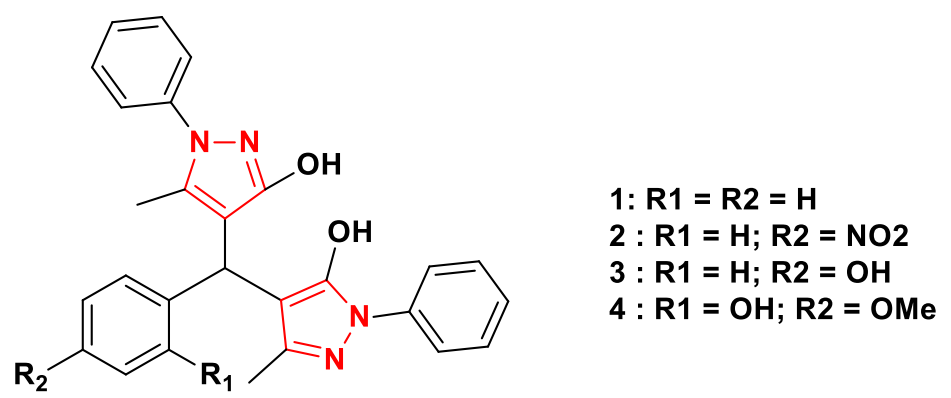

Figure 1. Structure of the pyrazoles 1-4 [25].

The 1-(2-benzothiazolyl)-3-methyl-pyrazol-5-one (5) (Figure 2) was synthesized and its ability to inhibit corrosion of ASTM A36 carbon steel in $1 \mathrm{~mol} \cdot \mathrm{L}^{-1} \mathrm{HCl}$ solution. The gravimetric method and quantum chemical parameters were used to evaluate the efficiency of the inhibitor and its adsorption capacity to the metal. Experimental results revealed that inhibition increases along with the concentration, reaching maximum inhibition of $93 \%$ at $600 \mathrm{mg} \cdot \mathrm{L}^{-1}$. In addition, it was observed that the adsorption of the compound $\mathbf{5}$ on the carbon steel surface obeys the Langmuir isotherm. Therefore, the theoretical and experimental results agree, showing that the inhibitor studied has a great anti-corrosion potential [26]. 


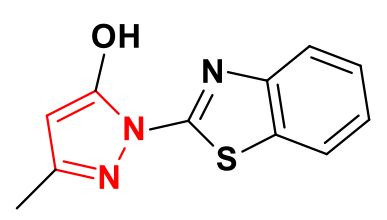

5

Figure 2. Structure of compound 5 [26].

Pyrazole pyridine $\mathbf{6}$ and pyrazole benzoic acid $\mathbf{7}$ were synthesized and evaluated as corrosion inhibitors for mild steel in a $1 \mathrm{M} \mathrm{HCl}$ medium. The evaluation was performed by electrochemical impedance spectroscopy (EIS), potentiodynamic polarization, and weight loss measurement. Both derivatives, 6 and 7, showed good inhibition efficiency that is dependent on inhibitor concentration, acting as mixed-type inhibitors. The benzoic acid derivative 7 showed a higher efficiency than $\mathbf{6}$, which could be attributed to the carboxyl group that is located at the para position to the amino group. Results also show that, they obey Langmuir adsorption isotherm. The relationship between the molecular structures and inhibition efficiencies of $\mathbf{6}$ and $\mathbf{7}$ where performed theoretically [27].

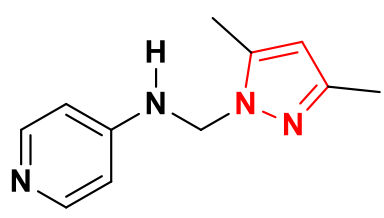

$\underline{6}$

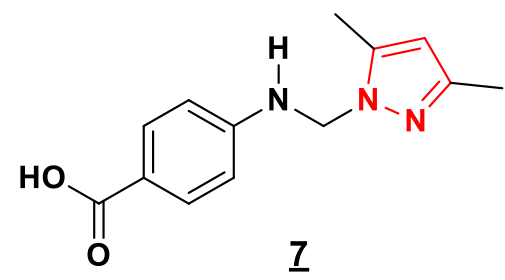

$\underline{7}$

Figure 3. Structure of compounds 6, 7 [27].

4-(bis((3,5-dimethyl-1H-pyrazol-1-yl)methyl)amino)benzonitrile 8 and 4-(bis $((1 \mathrm{H}-$ pyrazol-1-yl) methyl)amino)benzonitrile 9 were prepared and have been studied for their inhibition efficiencies against corrosion of mild steel in $1 \mathrm{M} \mathrm{HCl}$ solution by weight loss and electrochemical measurements. The inhibition efficiency using weight loss measurement reached $92.4 \%$ for 8 and $92.3 \%$ for 9 at the highest concentration $10^{-3} \mathrm{M}$. They act as mixed type inhibitors according to the Langmuir adsorption isotherm. The impedance diagrams in the Nyquist presentation and DFT method have confirmed the experimental results [28].

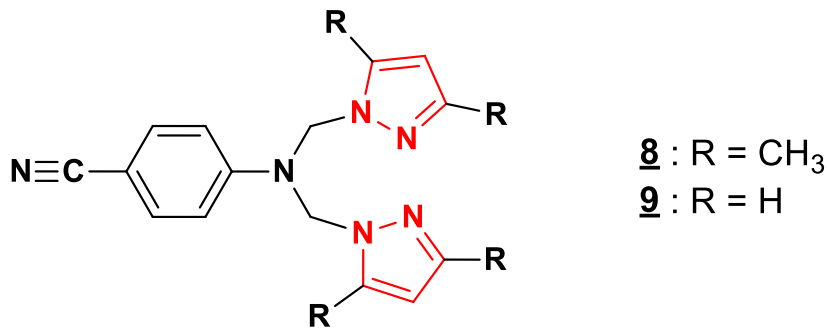

Figure 4. Structure of compounds 8,9 [28]. 
The 1-ethyl-1H-pyrazolo[3,4-d]pyrimidine-4(5H)-thione $\mathbf{1 0}$ and 1-methyl-4methylsulfanyl-1 $H$-pyrazolo[3,4-d]pyrimidine $\mathbf{1 1}$ have been evaluated as corrosion inhibitor for mild steel in $1 \mathrm{M} \mathrm{HCl}$ solution by means of potentiodynamic polarization and electrochemical impedance spectroscopic measurements. The obtained results revealed that this compound is a good mixed type inhibitor with cathodic predominance effectiveness. The effect of temperature on the corrosion behavior with the addition of optimal concentration of $10^{-3} \mathrm{M}$ was studied in temperature range of $303-343 \mathrm{~K}$. The value of inhibition efficiency decreases slightly with the increasing of temperature. The adsorption of the inhibitor on the mild steel (MS) surface follows the Langmuir adsorption isotherm, indicating monolayer adsorption. The activation parameters indicate the inhibitor is physically adsorbed. Quantum chemical calculations were used to correlate the inhibition ability of $\mathbf{1 1}$ with its electronic structural parameters [29, 30].

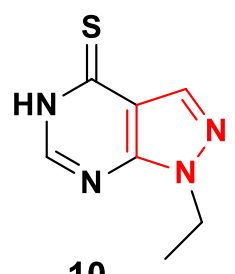

10

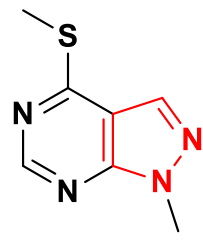

11

Figure 5. Structure of compounds $\mathbf{1 0}$ and $\mathbf{1 1}[29,30]$.

The inhibition performance and mechanism of N1,N1,N3,N3-tetrakis((3,5-dimethyl1H pyrazol-1-yl)methyl)propane-1,3-diamine 12 and N1,N1,N2,N2-tetrakis((3,5-dimethyl1H-pyrazol-1-yl)methyl)benzene-1,2-diamine 13 for the corrosion of mild steel in $1 \mathrm{M} \mathrm{HCl}$ were investigated using weight loss method and electrochemical measurements. The results show that both tetrakis pyrazole derivatives act as good inhibitors, and inhibition efficiency follows the order: 13>12. Two tetrakis pyrazole derivatives are mixed type inhibitors exhibiting predominantly cathodic behavior. The Nyquist plots showed that, after increasing inhibitor's concentrations, charge-transfer resistance increased and double-layer capacitance decreased, involving increased inhibition efficiency. The adsorption of both inhibitors on a steel surface obeyed Langmuir model, and theoretically studies in good correlation with experimental results [31].

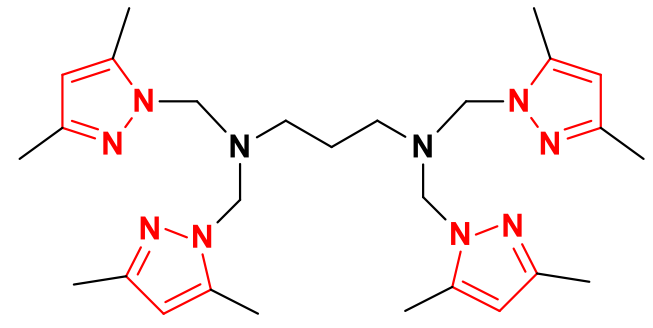

12

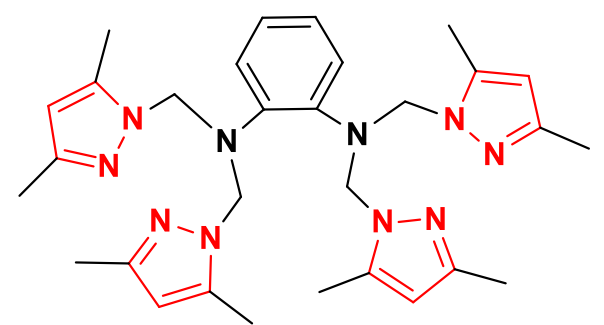

13

Figure 6. Structure of compounds 12 and 13 [31]. 
A new corrosion inhibitor namely 2-[Bis-(3,5-dimethyl-pyrazol-1-ylmethyl)-amino]-3hydroxy-butyric acid $\mathbf{1 4}$ has been synthesized and investigated its inhibitive performance towards the corrosion of carbon steel in $1 \mathrm{M}$ hydrochloric acid using usual techniques. The efficiency of the inhibitor increases with increase in the inhibitor concentration. Results obtained reveal that the used Bipyrazole derivative performs as corrosion inhibitor for carbon steel in $1 \mathrm{M} \mathrm{HCl}$. The adsorption of this compound on carbon steel surface is found to obey Langmuir adsorption isotherm [32].

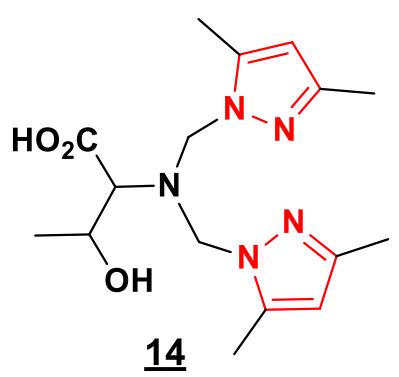

Figure 7. Structure of compound 14 [32].

The $\left\{N, N^{\prime}\right.$-bis-[(3,5-dimethyl-1H-pyrazol-1-yl)methyl]- $N, N^{\prime}$-dimethylethane-1,2diamine 15 and $N, N^{\prime}$-bis[(3-ethylcarboxylate-5-methyl-1 $H$-pyrazol-1-yl)methyl]- $N, N^{\prime}$ dimethyl ethane-1,2-diamine $\mathbf{1 6}$ have been studied as organic inhibitors for corrosion for mild steel in $1 \mathrm{M} \mathrm{HCl}$. All the techniques employed are in good agreement between them. The protection efficiency rises with increasing inhibitors concentrations and increasing temperature too [33]

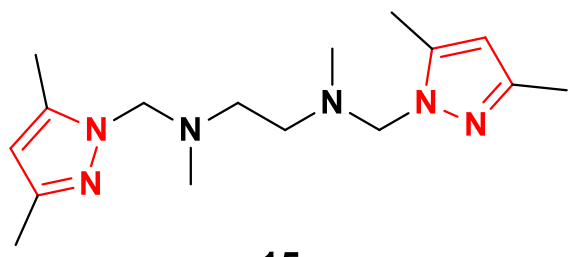

15

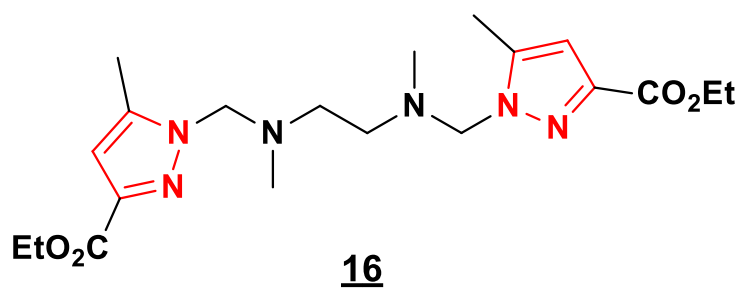

16

Figure 8. Structure of compounds 15, 16 [33].

The quantum chemical calculations based on the DFT method on two bipyrazoles 1718 used as corrosion inhibitors for the plain carbon ("mild") steel in acid media. This study shows the relationship between inhibition efficiency and the molecular structure of inhibitors are in good agreement [34]. 

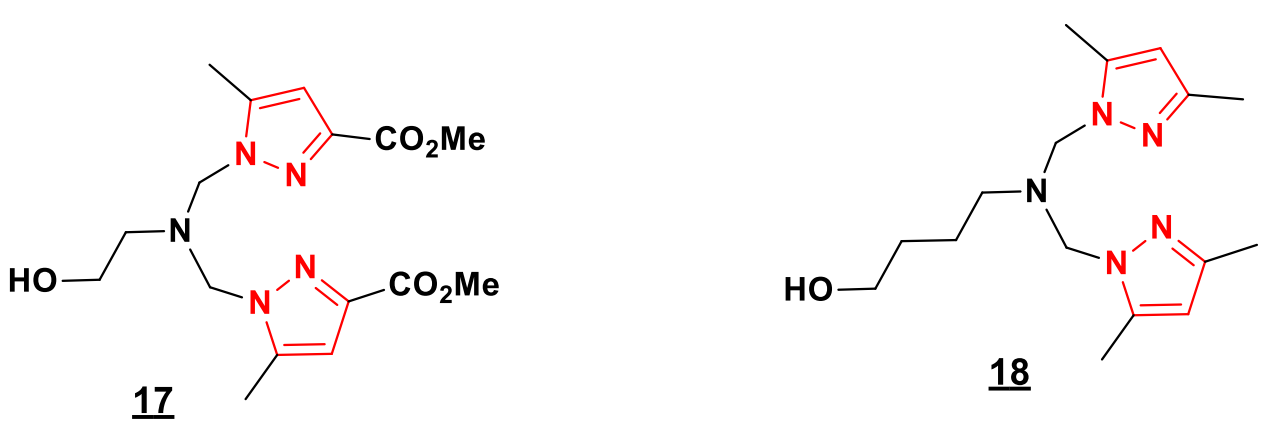

Figure 9. Structure of compounds 17, 18 [34].

The effect of synthesized 1,1'-propane-1,3-diylbis[3-(chloromethyl)-5-methyl-1Hpyrazole] 19, dimethyl 1,1'-butane-1,4-diylbis(5-methyl-1H-pyrazole-3-carboxylate) 20 and 1,1'-butane-1,4-diylbis[3-(chloromethyl)-5-methyl-1H-pyrazole] 21 on corrosion of C38 steel in hydrochloric acid solution has been investigated in the temperature range from $298 \mathrm{~K}$ to $328 \mathrm{~K}$ by weight loss, potentiodynamic polarization method and modelled with an equivalent electric circuit. All the compounds exhibited more than $90 \%$ anticorrosion activity, the highest is $96 \%$ by $\mathbf{2 1}$, and it has been shown that the inhibition efficiencies increased with the concentration of the inhibitors, remaining almost constant in a wide temperature range. Potentiodynamic polarization studies suggested that it is a predominance cathodic type. Nyquist plots showed depressed semicircles with their center below the real axis. The adsorption on the C38 steel surface followed the Langmuir adsorption isotherm. The thermodynamic parameters for dissolution were investigated at different concentrations and temperature. The theoretical study by modelling the molecules of these inhibitors has been performed by considering the Density Functional Theory (DFT) using the Gaussian $03 \mathrm{~W}$ suite of programs that can calculate the different quantum parameters such as $E_{\mathrm{HOMO}}$, $E_{\mathrm{LUMO}}, D E_{\mathrm{HOMO}}, E_{\mathrm{LUMO}}$, and $\mu$ dipolar moment, allowing us to confirm the results found by the gravimetric and electrochemical methods [35].

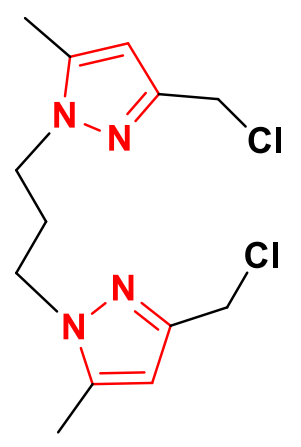

$\underline{19}$

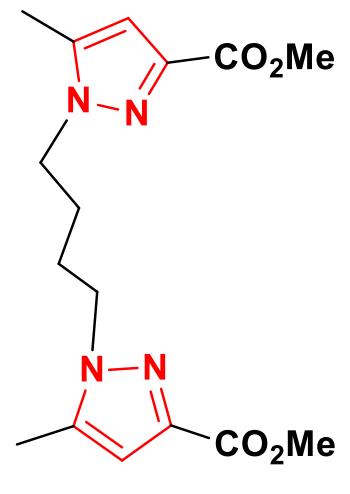

$\underline{20}$

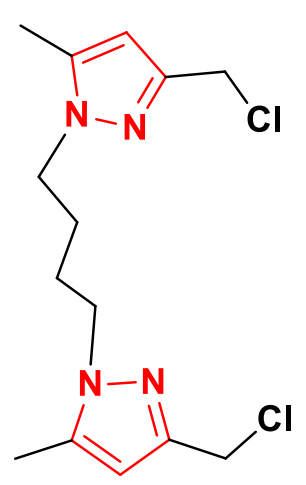

$\underline{20}$

Figure 10. Structure of compounds 19, 20 [35]. 
The corrosion inhibition of mild steel in $1 \mathrm{M} \mathrm{HCl}$ solution by $N, N^{\prime}$-bis[(3,5-dimethyl1H-pyrazol-1-yl)methyl]piperazine $\mathbf{2 1}$ and $N, N^{\prime}$-bis[(3-ethylcarboxylate-5-methyl-1Hpyrazol-1-yl)methyl]piperazine $\mathbf{2 2}$ was studied using usual techniques. These measurements show that the inhibition efficiency obtained by these compounds increased by increasing their concentrations. to attain $91 \%$ for $\mathbf{2 1}$ and $92 \%$ for $\mathbf{2 2}$ since $10^{-3} \mathrm{M}$ [36].

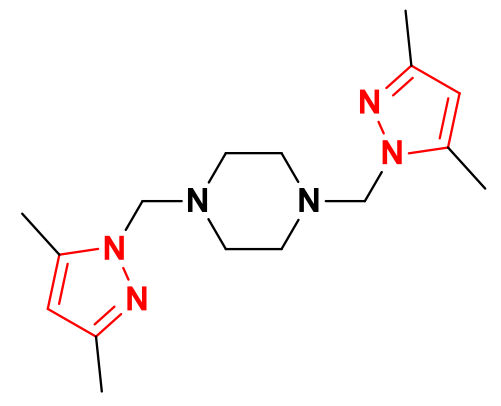

$\underline{21}$

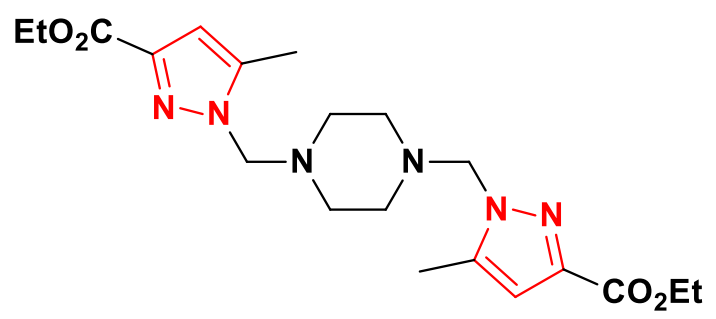

$\underline{22}$

Figure 11. Structure of compounds 21, 22 [36].

Three bipyrazole derivatives, 1,1',5,5'-tetramethyl-1H,1'H-3,3'-bipyrazole 23, Ethyl5,5'-dimethyl-1'H-1,3'-bipyrazole-4-carboxylate $\mathbf{2 4}$, and 3-(bromomethyl)-5,5'-dimethyl$1^{\prime} \mathrm{H}-1,3^{\prime}$-bipyrazole 25 , have been synthesized and used as additives to protect $\mathrm{C} 38$ steel from corrosion in aerated $1 \mathrm{M} \mathrm{HCl}$ solution, using the various corrosion monitoring techniques such as weight loss, potentiodynamic polarization, and electrochemical impedance spectroscopy. All the techniques used for the studies show an increase in inhibition efficiency and decrease in the corrosion rate by increasing the inhibitor concentration $[37,38]$.

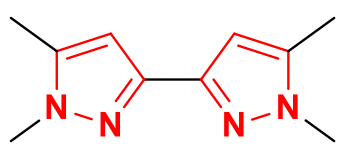

$\underline{23}$

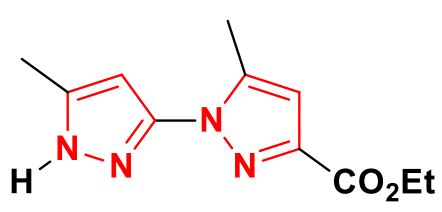

$\underline{24}$

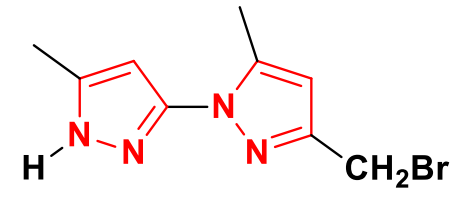

$\underline{25}$

Figure 12. Structure of compounds $23-\mathbf{2 5}$ [37, 38].

The corrosion and inhibitors adsorption processes in mild steel of two tripodal pyrazolic compounds 3-[bis-(3,5-dimethyl-pyrazol-1-ylmethyl)-amino]-propan-1-ol 26 and 1-[bis-(3carbomethoxy-5-methyl-pyrazol-1-ylmethyl)-amino]-propan-2-ol 27 in hydrochloric acid solution were studied at different temperatures $(308-323 \mathrm{~K})$ by means weight loss (WL) measurements. It has been found that the studied compounds exhibit a very good performance as inhibitors for mild steel corrosion in $1 \mathrm{M} \mathrm{HCl}$. These results show that the inhibition efficiency increases with decreasing temperature and increasing concentration of inhibitors. It has been determined that the adsorption for the studied inhibitors on mild steel 
complies with the Langmuir adsorption. The kinetic and thermodynamic parameters for mild steel corrosion and inhibitor adsorption were determined and discussed, respectively. On the bases of thermodynamic adsorption parameters, comprehensive adsorption (physisorption and chemisorption) for the studied inhibitors on mild steel surface has been suggested [39].

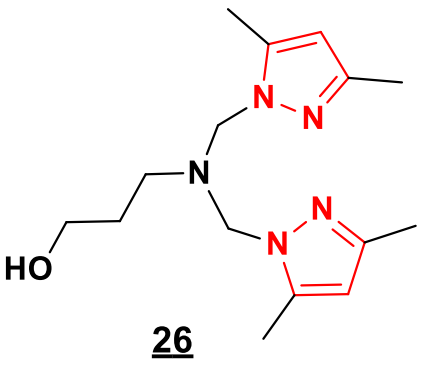

$\underline{26}$

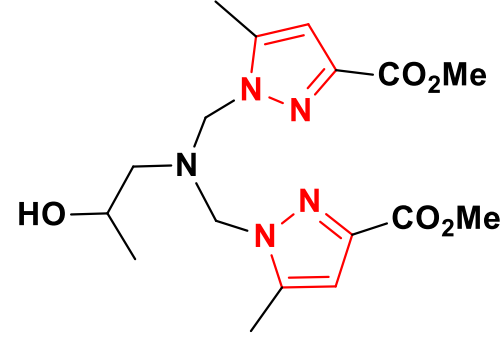

$\underline{27}$

Figure 13. Structure of compounds 26, 27 [39].

Corrosion inhibition of copper through six bipyrazolic compounds $\mathbf{2 8}-\mathbf{3 3}$ has been elucidated by means of density functional theory (DFT)-derived reactivity indexes. The DFT calculated parameters and experimental corrosion inhibition efficiency $(I E \%)$ indicate that their inhibition effect is closely related to the frontier orbital energies, polarizability, electronic chemical potential and global nucleophilicity. The quantum chemistry calculations were performed at the B3LYP/6-31G (d) level. The theoretical results, predicted using DFT-based reactivity indexes, are in good agreement with experimental outcomes [40, 41].

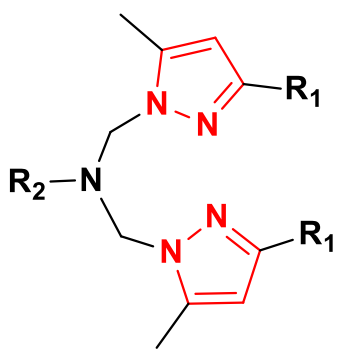
28: $\mathrm{R}_{1}=\mathrm{CH}_{3} ; \mathrm{R}_{2}=\mathrm{CH}_{2} \mathrm{CH}_{2} \mathrm{OH}$
29: $\mathrm{R}_{1}=\mathrm{CH}_{3} ; \mathrm{R}_{2}=\mathrm{CH}_{2} \mathrm{CH}=\mathrm{CH}_{2}$
30: $\mathrm{R}_{1}=\mathrm{CH}_{3} ; \mathrm{R}_{2}=\mathrm{CH}_{2} \mathrm{CH}_{2} \mathrm{CH}_{3}$
31: $\mathrm{R}_{1}=\mathrm{CH}_{3} ; \mathrm{R}_{2}=\mathrm{C}_{6} \mathrm{H}_{11}$
32: $\mathrm{R}_{1}=\mathrm{CO}_{2} \mathrm{CH}_{3} ; \mathrm{R}_{2}=\mathrm{C}_{6} \mathrm{H}_{11}$
33: $\mathrm{R}_{1}=\mathrm{CO}_{2} \mathrm{C}_{2} \mathrm{H}_{5} ; \mathrm{R}_{2}=\mathrm{C}_{6} \mathrm{H}_{11}$

Figure 14. Structure of compounds $\mathbf{2 8}-\mathbf{3 3}$ [40, 41].

The effect of some prepd. compounds, 3,5-dimethyl-1H-pyrazole 34, 3(5)-amino-5(3)methylpyrazole 35, and 1',3,5,5'-tetramethyl-1' $H$-1,3'-bipyrazole 36, on the corrosion behavior of steel in $1 \mathrm{M} \mathrm{HCl}$ solution as corrosive medium was studied at $308 \mathrm{~K}$ using weight loss measurement, potentiodynamic polarization, linear polarization, and impedance spectroscopy (EIS). Generally, inhibition efficiency of the studied compounds depends on the concentration and nature of the inhibitor. The compound $\mathbf{3 6}$ was a better inhibitor than 34 and 35, and its inhibition efficiency increased with increasing concentration of inhibitor [42]. 


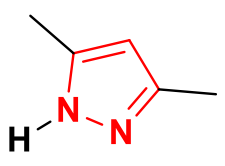

$\underline{34}$

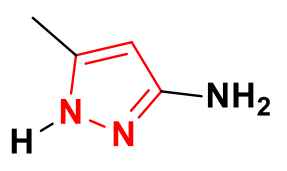

$\underline{35}$

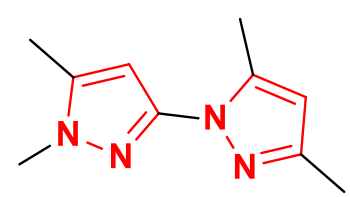

$\underline{36}$

Figure 15. Structure of compounds $34-36$ [42].

The inhibitor effect of two isomers namely $2-\left(1^{\prime}, 5,5^{\prime}\right.$-trimethyl- $1 \mathrm{H}, 1^{\prime} \mathrm{H}-3,3^{\prime}$-bipyrazol1-yl)ethanol 37 and 2-(1',5,5'-trimethyl-1H,2'H-3,3'-bipyrazol-2-yl)ethanol $\mathbf{3 8}$ on the corrosion of mild steel in $1 \mathrm{M}$ hydrochloric acid was investigated at $308 \mathrm{~K}$ using weight loss measurements and electrochemical techniques. Inhibition efficiency is dependent upon the pyrazole structure, with $\mathbf{3 7}$ serving as a better inhibitor than $\mathbf{3 8}$ and its inhibition efficiency increases with the increase of concentration of inhibitor to attain $93 \%$ in the presence of $10^{-3} \mathrm{M}[43]$.
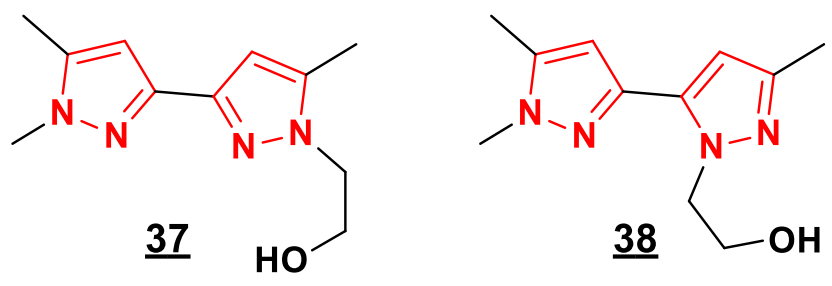

Figure 16. Structure of compounds 37, 38 [43].

In this study, some possible relationship between the experimental inhibition corrosion in acidic media and the theoretical energy calculations DFT, for six compounds 39-44 has been presented. These sets of compounds have been tested for their corrosion inhibition properties of steel in low concentration of hydrochloric acid medium [44].

A theoretical study of five bipyrazolic-type organic compounds, 4-\{bis[(3,5-dimethyl$1 H$-pyrazolyl-1-yl)methyl]-amino $\}$ phenol $\quad \mathbf{4 5}, \quad N 1, N 1$ - $\{$ bis[(3,5-dimethyl-1 $H$-pyrazol-1yl)methyl $\}]-N 4, N 4$-dimethyl-1,4-benzenediamine 46, $N, N$-bis[(3,5-dimethyl-1H-pyrazol-1yl)methyl]aniline 47, 4-[bis(3,5-di-Me-pyrazol-1-yl-methyl)-amino]butan-1-ol 18, ethyl-4[bis(3,5-dimethyl-1H-pyrazol-1-yl-methyl)aminobenzoate] 48, and $N$-benzyl- $N, N$-bis[(3,5dimethyl-1H-pyrazol-1-yl)methyl]amine 49 on the corrosion of steel in $1 \mathrm{M} \mathrm{HCl}$ was studied at $308 \mathrm{~K}$. Weight loss measurements, potentiodynamic polarization, and have been performed using (DFT) in order to elucidate the different inhibition efficiencies and reactive sites of these compounds [45-47]. 


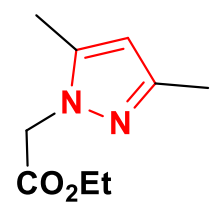

$\underline{39}$

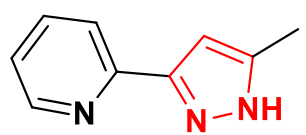

$\underline{41}$

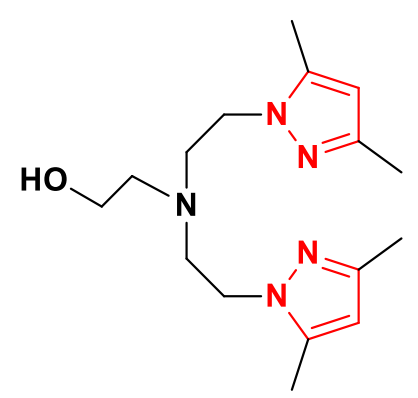

$\underline{43}$

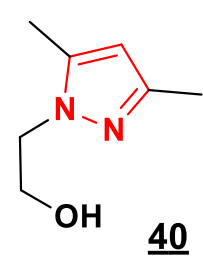

$\underline{40}$
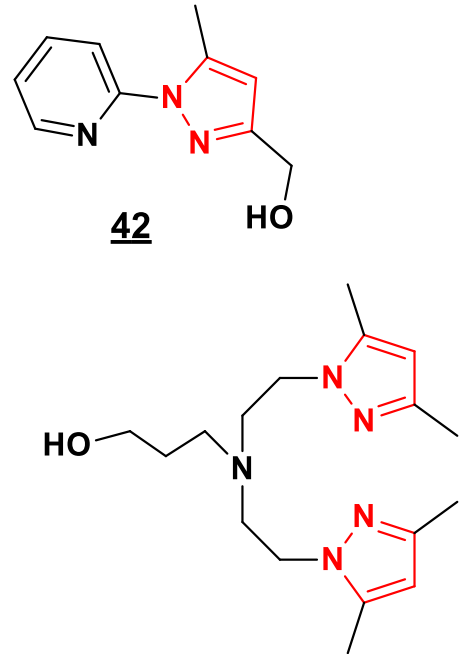

$\underline{44}$

Figure 17. Structure of compounds 39-43 [44].

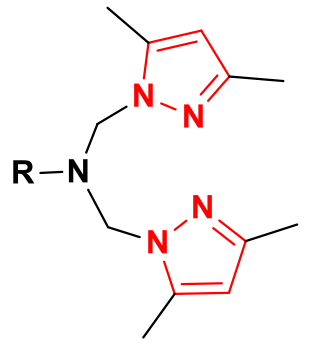

18: $\mathrm{R}=\left(\mathrm{CH}_{2}\right)_{4}$

45: $R=O H P h$

46: $\mathrm{R}=\mathrm{N}\left(\mathrm{CH}_{3}\right)_{2} \mathrm{Ph}$

47: $\mathrm{R}=\mathrm{Ph}$

48: $\mathrm{R}=\mathrm{CO}_{2} \mathrm{EtPh}$

$\underline{49}: \mathrm{R}=\mathrm{CH}_{2} \mathrm{Ph}$

Figure 18. Structure of compounds 18, 45-49 [45-47].

Potentiodynamic polarization, electrochemical impedance spectroscopy and weight loss studies were carried out on the inhibition of carbon steel in $1 \mathrm{M} \mathrm{HCl}$ solution by 5,5dipropyl-1H,1H-[3,3]bipyrazolyl 50, 5,5-diphenyl- $1 H, 1 H$-[3,3]bipyrazolyl $\mathbf{5 1}$ and 5,5-bis(4-chloro-phenyl)- $1 H, 1 H$-[3,3]bipyrazolyl 52. All measurements show that inhibition efficiency increases with increase in inhibitor concentration and the variation in inhibitive efficiency mainly depends on the type and nature of the substituents present in the inhibitor molecule to attain $98 \%$ for chloro derivative 52 at $10^{-3} \mathrm{M}$. This reveals that inhibitive actions of bipyrazolic compounds were mainly due to adsorption on steel surface and theoretical investigations were well correlated with the experimental ones [48]. 


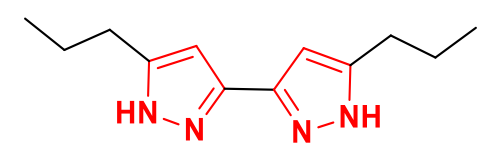

$\underline{50}$

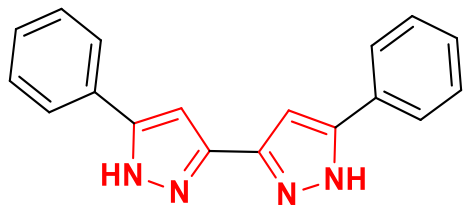

$\underline{51}$

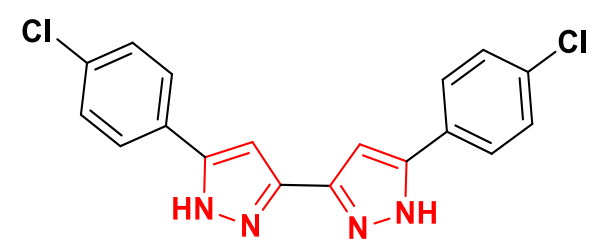

$\underline{52}$

Figure 19. Structure of compounds 50-52 [48].

The influence of 3,5-dimethyl-1H-pyrazole 53, and 2-(3-methyl- $1 H$-pyrazol-5-yl) pyridine 54 on the corrosion inhibition of carbon steel in $1 \mathrm{M} \mathrm{HCl}$ solution was studied by using weight-loss, potentiodynamic and EIS measurements. The compound $\mathbf{3 4}$ was the best inhibitor, and its inhibition efficiency increases with increasing inhibitor concentration to attain $89 \%$ at $10^{-3} \mathrm{M}$. Potentiodynamic polarization studies clearly reveal that it acts essentially as a cathodic inhibitor. The efficiency values obtained by the various methods used were in agreement [49].

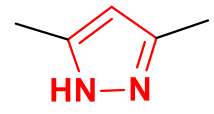

$\underline{34}$

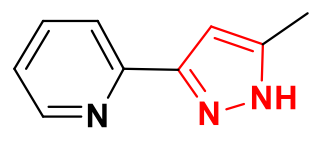

$\underline{41}$

Figure 20. Structure of compounds 41, 34 [49].

The study the effect of inhibition of new bipyrazole derivatives on the corrosion of steel in $\mathrm{HCl}$ media at various temperature. The design of novel corrosion inhibitors, bipyrazoles were tested as corrosion inhibitors for steel in $1 \mathrm{M} \mathrm{HCl}$, ethyl-5,5'-dimethyl-1' $H-1,3^{\prime}$ bipyrazole-3-carboxylate 24 and 3,5,5'-trimethyl-1' $H$-1,3'-bipyrazole 54, 1,5,5'-trimethyl$1 H, 2^{\prime} H$-3,3'-bipyrazole 55, ethyl 1',5,5'-trimethyl-1' $H$-1,3'-bipyrazole-3-carboxylate $\mathbf{5 6}$ and $1^{\prime}, 5,5^{\prime}$-trimethyl-1'H-1,3'-bipyrazol-3-yl)methanol 57 on the corrosion behavior of steel in $1 \mathrm{M} \mathrm{HCl}$ solution was studied at $308 \mathrm{~K}$ by weight loss measurements, potentiodynamic polarization and impedance spectroscopy (EIS) methods. The inhibition efficiencies obtained from cathodic Tafel plots, gravimetric and EIS methods are in good agreement. The compound 54 is the best inhibitor and its efficiency reaches $84 \%$ at $10^{-3} \mathrm{M}$ and acts as cathodic-type inhibitors [50, 51].

The inhibiting action of six bipyrazolic isomers, namely, 4-\{bis[(1,5-dimethyl- $1 H$ pyrazolyl-3-yl)methyl]amino $\}$ phenol 58, 4-\{bis[(3,5-dimethyl-1 $H$-pyrazolyl-1-yl)methyl]amino phenol 45, $N, N$-bis[(3,5-dimethyl-1 $H$-pyrazol-1-yl)methyl]- $N$-(4-methylphenyl)amine 61 and methyl 1-[((methylphenyl)\{[3-(methoxycarbonyl)-5-methyl-1H-pyrazol-1yl]methyl \}amino)methyl]-5-methyl-1H-pyrazole-3-carboxylate $\mathbf{6 0}$ for the corrosion of steel in $1 \mathrm{M} \mathrm{HCl}$ solution has been investigated at $308 \mathrm{~K}$ by using weight loss measurements, polarization and impedance spectroscopy methods. The inhibition efficiencies evaluated from the methods used are in agreement. The polarization curves reveal that these 
bipyrazolic compounds $45,58,60-63$ act as mixed-type inhibitors and are efficient inhibitors. Their inhibition efficiencies reached $c a .95 \%$ for both isomers at $5 \cdot 10^{-4} \mathrm{M}$ concentration (308-353 K) [52-54].

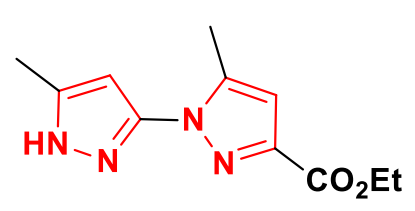

$\underline{24}$

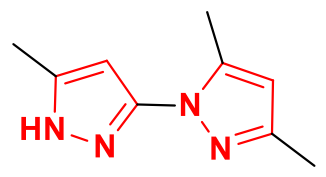

$\underline{54}$

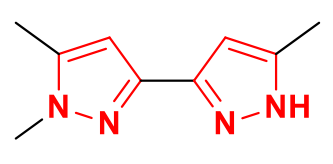

$\underline{55}$

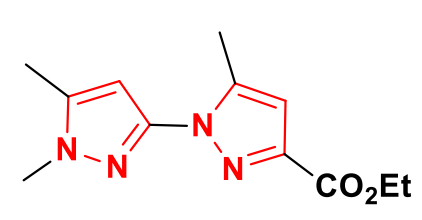

$\underline{56}$

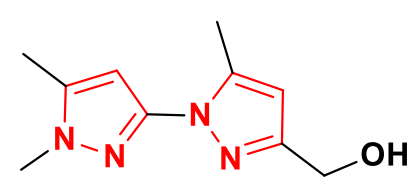

$\underline{57}$

Figure 21. Structure of compounds 24, 54-57 [50, 51].

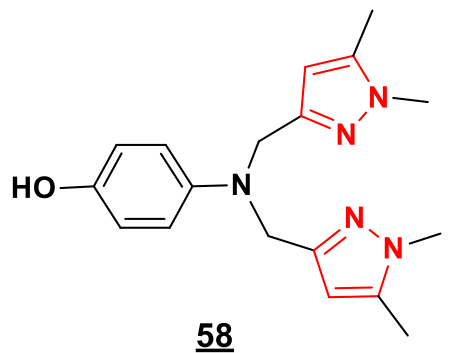

$\underline{58}$

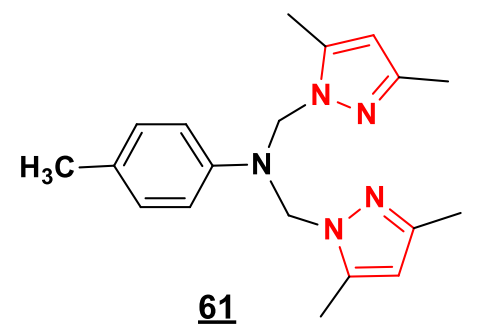

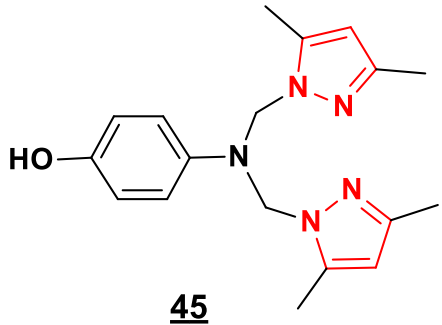

$\underline{45}$

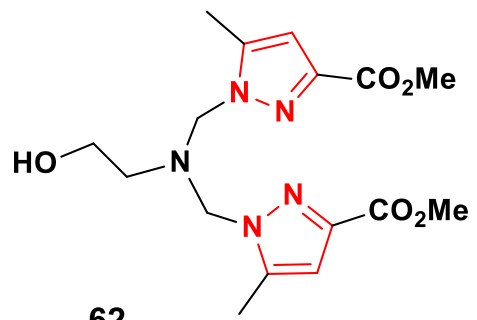

$\underline{62}$

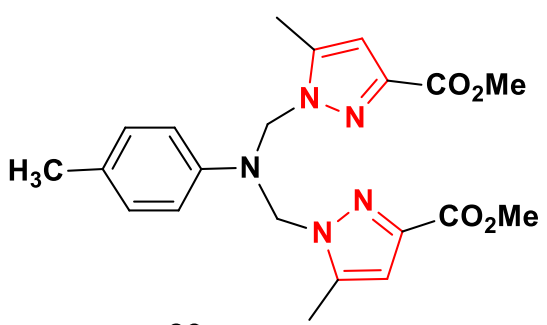

$\underline{60}$

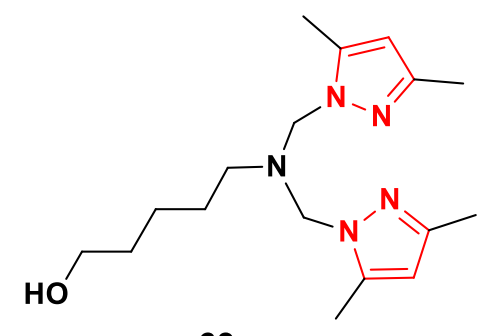

$\underline{63}$

Figure 22. Structure of compounds $45,58,60-63[52,54]$.

The inhibition of the corrosion of steel in $1 \mathrm{M} \mathrm{HCl}$ by two pyridine-pyrazole type organic compounds (5-methyl-1-pyridin-2-yl-1H-pyrazol-3-yl)methanol 64 and ethyl 5methyl-1-pyridin-2-yl-1H-pyrazol-3-carboxylate $\mathbf{6 5}$ has been studied at $308 \mathrm{~K}$ by weight loss, electrochemical polarization, polarization resistance and electrochemical impedance spectroscopy (EIS) measurements. The inhibition efficiencies obtained from cathodic Tafel plots gravimetric and EIS methods were in good agreement. The results obtained reveal that these compounds. are efficient inhibitors. The inhibition efficiency increases with the increase of inhibitor concentration and reached $94 \%$ for 64 at $10^{-3} \mathrm{M}$. Potentiodynamic polarization studies clearly reveal that the presence of inhibitors 63 and 64 does not change 
the mechanism of hydrogen evolution and that they act essentially as cathodic inhibitors. The inhibitors were adsorbed on the steel surface according to the Frumkin adsorption isotherm model [55].

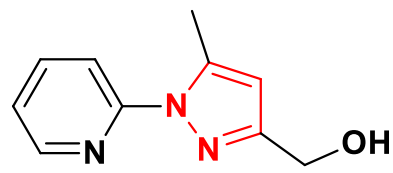

$\underline{64}$

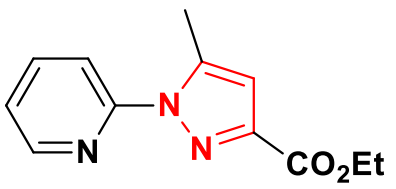

$\underline{65}$

Figure 23. Structure of compounds 64-65 [55].

The inhibition of corrosion of steel in $1 \mathrm{M} \mathrm{HCl}$ solution by pyrazole derivatives 63 and 66 was studied by weight loss and polarization techniques at $308 \mathrm{~K}$. The results obtained reveal that tripyrazole exhibits a good protection. Inhibition is found to increase with increase in inhibitor concentration. The inhibition behavior of the compound was explained on the basis of molecular size and charge distribution of adsorption active centers. The adsorption phenomenon obeys the Langmuir adsorption isotherm model [56].

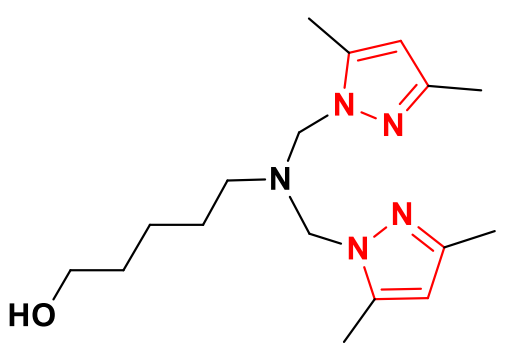

$\underline{63}$

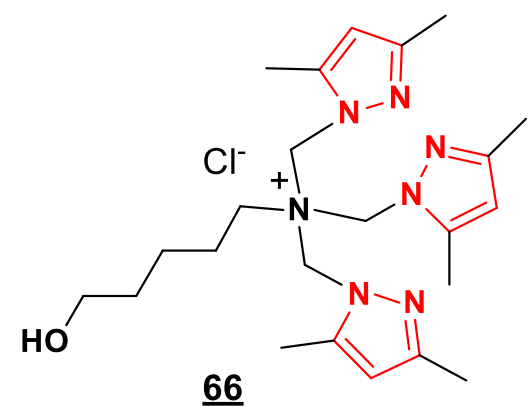

$\underline{66}$

Figure 24. Structure of compounds 63, 66 [56].

Bipyrazolic compounds 19, 67-69 were tested as corrosion inhibitors for lead in $0.3 \mathrm{M}$ hydrochloride acid using potentiodynamic measurement and gravimetric methods. Results obtained showed that bis(3-carbomethoxy-5-methyl-1-pyrazolyl)methane $\mathbf{6 7}$ was the best inhibitor and its inhibition efficiency reaches a value of $88 \%$ at $10^{-3} \mathrm{M}$. Polarization measurements indicated that the $c . d$. decreases with increasing inhibitor concentration all these ligands were adsorbed on the lead surface according to a Langmuir isotherm model. The effect of temperature indicated that inhibition efficiency of these compounds decreases with increasing temperature at 298-343 K [57-65]. 


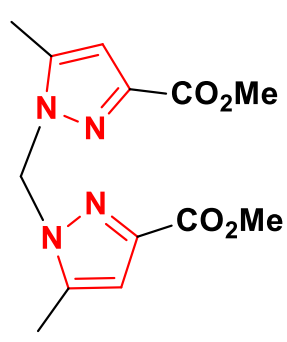

$\underline{67}$

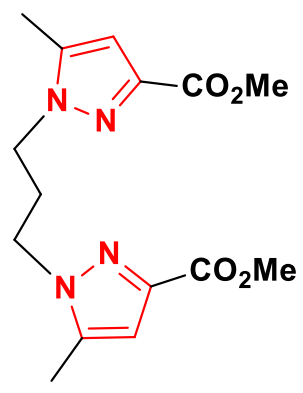

$\underline{68}$

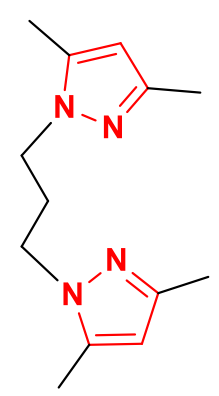

$\underline{69}$

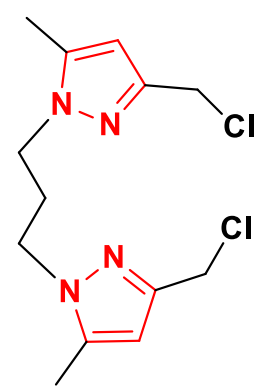

$\underline{19}$

Figure 25. Structure of compounds 19, 67-69 [57-65].

\section{Inhibition of corrosion by pyrazole moieties in $\mathrm{H}_{2} \mathrm{SO}_{4}$ media}

The corrosion inhibition of mild steel in $0.5 \mathrm{M} \mathrm{H}_{2} \mathrm{SO}_{4}$ using ethyl 1-(((4-acetylphenyl)((3-(ethoxycarbonyl)-1H-pyrazol-1-yl)methyl)amino)methyl)-5-methyl-1H-pyrazole-3carboxylate 70 at $298 \mathrm{~K}$ have been investigated. The study was performed using weight loss method, potentiodynamic polarization, and electrochemical impedance spectroscopy (EIS). The experimental results suggest that the inhibition efficiency of this compound increases with the increase in inhibitor concentration. Adsorption of this compound on mild steel surface obeys Langmuir's isotherm. Polarization measurements proved that this inhibitor behave as mixed type. EIS data showed that the charge transfer resistance of mild steel increases in acid solution containing inhibitor. Correlation between quantum chemical calculations and inhibition efficiency of the investigated compound is discussed using the Density Functional Theory method (DFT) [66].

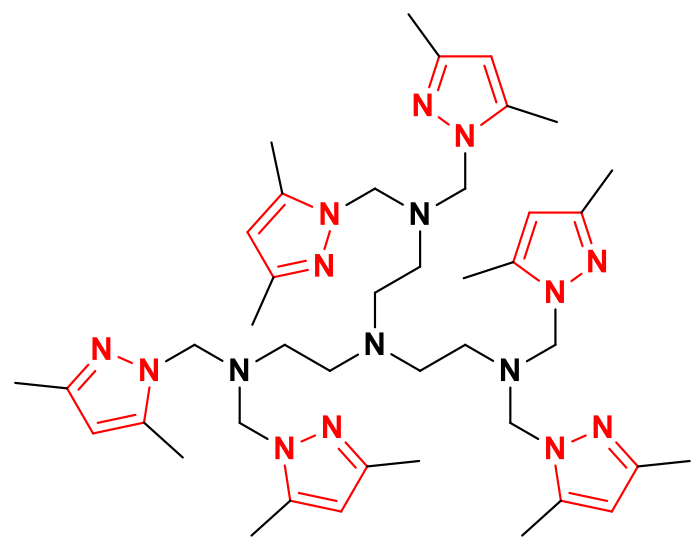

$\underline{70}$

Figure 26. Structure of compound 70 [66].

The corrosion inhibition of mild steel in $0.5 \mathrm{M} \mathrm{H}_{2} \mathrm{SO}_{4}$ in the presence of N1,N1-bis(2(bis((3,5-dimethyl-1H-pyrazol-1-yl)methyl)amino)ethyl)- $N 2, N 2$-bis((3,5-dimethyl- $1 H$ pyrazol-1-yl)methyl)ethane-1,2-diamine $\mathbf{7 1}$ has been studied by electrochemical techniques (DC polarization and AC impedance) and weight loss measurement. Result obtained reveal 
that this pyrazole derivative is good inhibitor for mild steel in $0.5 \mathrm{M} \mathrm{H}_{2} \mathrm{SO}_{4}$. Tafel polarization studies clearly reveal the type of inhibitor. This pyrazole derivative acts on cathodic and anodic reactions and reduces corrosion current density. Changes in impedance parameters $\left(R_{\mathrm{ct}}\right.$ and $\left.C_{\mathrm{dl}}\right)$ are indicative of adsorption of the pyrazole derivative on the metal surface leading to formation of protective film which grows with increasing concentration and inhibition efficiency values increase. The effect of temperature on the corrosion behavior of mild steel with the addition of the pyrazole derivative was studied in the temperature range from 303 to $333 \mathrm{~K}$. Thermodynamic parameters for adsorption and activation processes were determined. Adsorption of this inhibitor follows the Langmuir adsorption isotherm [67].

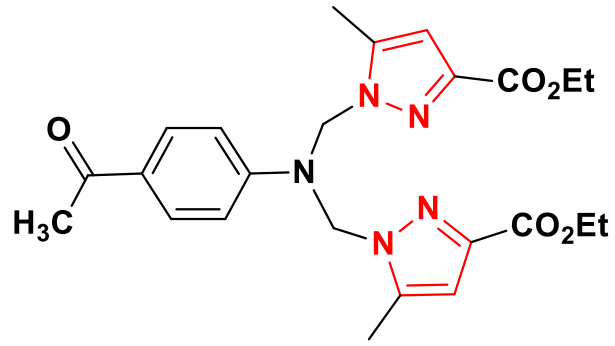

$\underline{71}$

Figure 27. Structure of compound 71 [67].

The 2-[bis-(3,5-dimethyl-pyrazol-1-ylmethyl)-amino]-4-[bis-(3,5-dimethyl-pyrazol-1ylmethyl)carbamoyl]-butyric acid $\mathbf{7 2}$ has been evaluated as a corrosion inhibitor for carbon steel using weight loss and electrochemical polarization (EIS). The study was also complemented by SEM (SEM) and quantum chemical calculations. The inhibition efficiency $(\eta \%)$ increased with increasing $\mathbf{7 2}$ concentration, showing a maximum IE of $93.5 \%$ at $298 \mathrm{~K}$ at $10^{-3} \mathrm{M}$ and decreased with increasing temperature. The electrochemical studies showed that 72 inhibitor retards both cathodic and anodic processes through the inhibitor adsorption on the surface [68].

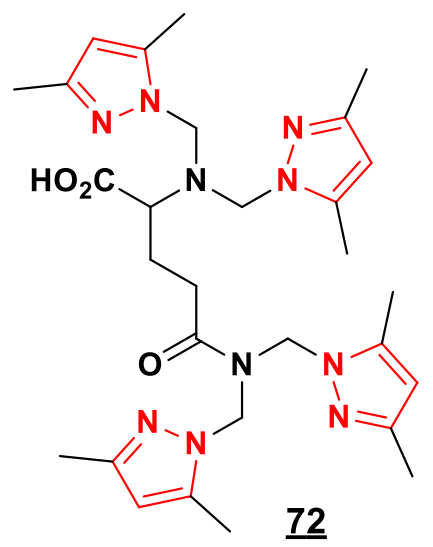

Figure 28. Structure of compound 72 [68]. 
The effect of addition of 1,3-bis(3-hydroxymethyl-5-methyl-1-pyrazole) propane $\mathbf{7 2}$ on steel corrosion in $0.5 \mathrm{M}$ sulfuric acid is studied by weight loss, electrochemical polarization and electrochemical impedance spectroscopy (EIS) measurements at various temps. The results obtained showed that $\mathbf{7 2}$ acts as a good corrosion inhibitor. The inhibition efficiency increases with the bipyrazole compd. to attain $88 \%$. It acts as a mixed-type inhibitor. Trends in the increase of charge-transfer resistance and decrease of capacitance values also show the adsorption of the molecule on the metal surface. The bipyrazole adsorbs on the steel surface according to the Langmuir isotherm adsorption model. Effect of temperature indicates that inhibition efficiency decreases with temp. between 25 and $85^{\circ} \mathrm{C}$ [69].

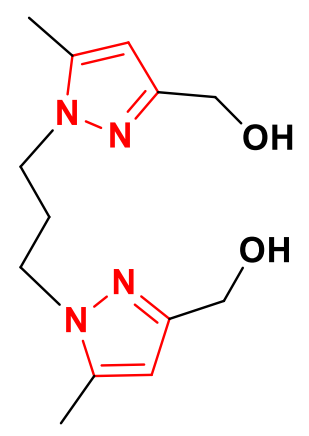

$\underline{73}$

Figure 29. Structure of compound 73 [69].

\section{Inhibition of corrosion by pyrazole moieties in $\mathrm{NaCl}$ media}

The corrosion behavior of copper in aerated $3 \% \mathrm{NaCl}$ solution was investigated by rotating electrode at various rates. The rendement of $\mathrm{O}_{2}$ obeys the Levich equation. The inhibition of the copper corrosion in aerated $3 \% \mathrm{NaCl}$ solution was studied by using potentiodynamic polarization and linear polarization resistance (LRP) in the presence of different concentrations of a bipyrazolic compound named N,N-bis(3-carbomethoxy-5methylpyrazol-1-ylmethyl)cyclohexylamine 33 (Figure 15). The presence of this compound in the solution decreases the corrosion $c . d$. and increases the linear resistance polarization [70]. The inhibition of the copper corrosion in aerated 3\% $\mathrm{NaCl}$ solution was studied by using electrochemical polarization, weight loss and impedance measurements in the presence of different concentration of synthesized bipyrazolic compounds (Figure 15). The inhibition efficiencies obtained from cathodic Tafel plots, polarization resistance and weight loss are in agreement with electrochemical impedance spectroscopy measurements. All these additives were excellent inhibitors for copper corrosion. The difference in inhibition efficiencies of these inhibitors was not large, but the optimum concentration for maximum efficiency was slightly dependent on the substitution of each molecule. The studied molecules act as mixed-type inhibitors. Detailed study of inhibition shows that the maximum inhibition efficiency was approximately $99 \%$ with $5.10^{-4} \mathrm{M}$ of inhibitor. The latter adsorbs 
on the copper surface according to the Frumkin isotherm model. The inhibition efficiency of inhibitors decreases with increasing temperatures in the range $25-60^{\circ} \mathrm{C}$ [71].

\section{Inhibition of corrosion by pyrazole moieties in $\mathrm{H}_{3} \mathrm{PO}_{4}$ media}

The effect of a ruthenium-ligand complex $\mathbf{7 4}$ on the corrosion of steel in $2 \mathrm{M} \mathrm{H}_{3} \mathrm{PO}_{4}$ has been investigated at various temperatures using electrochemical techniques (impedance spectroscopy (EIS), polarization curves) and weight loss measurements. Inhibition efficiency $(E \%)$ increases with $\mathbf{7 4}$ concentration to attain $90 \%$ at $5 \times 10^{-4} \mathrm{M}$. EIS measurements show that the dissolution process of steel occurs under activation control. Polarization curves indicate that $\mathbf{7 4}$ acts as a cathodic inhibitor. E\% values obtained from various methods used are in good agreement. The temperature effect on the corrosion behavior of steel in $2 \mathrm{M} \mathrm{H}_{3} \mathrm{PO}_{4}$ without and with the inhibitor at various concentrations was studied in the temperature range from 298 to $338 \mathrm{~K}$. Thermodynamic parameters such as adsorption heat $\left(\Delta H_{\text {ads }}\right)$, adsorption entropy $\left(\Delta S_{\text {ads }}\right)$ and adsorption free energy $\left(\Delta G_{\text {ads }}\right)$ have been calculated. Kinetic parameters for the corrosion reaction at different concentrations of 74 were determined. Adsorption of $\mathbf{7 4}$ on the mild steel surface in $2 \mathrm{M} \mathrm{H}_{3} \mathrm{PO}_{4}$ follows the Langmuir isotherm model [72].

Pyrazole compounds received recently more attention by researchers in corrosion protection as well as biological activities [73-80]. Pyrazole compounds form on the metallic surface according to physical and/or chemical layer, and the formation organic-metal ion complexes at the surface can explain the decrease of current densities at anodic branch. The DFT method at B3LYP/6-31G $(\mathrm{d}, \mathrm{p})$ is an important tool to correlate results obtained theoretically with those obtained experimentally.

The nature of mineral acid affects the inhibitory action of organic inhibitor, in fact, the most studied pyrazole derivatives acted as mixed type inhibitors in $\mathrm{HCl}$ media, can lose activity on anodic reaction, this behavior may be explained by the nature of counter ion of $\mathrm{H}^{+}$as $\mathrm{Cl}^{-}, \mathrm{HSO}_{4}^{-}, \mathrm{H}_{2} \mathrm{PO}_{4}^{-}, \mathrm{HPO}_{4}^{2-} \ldots \mathrm{Cl}^{-}$is known as non-alkaline ion, the others have alkaline effect at the metal surface.

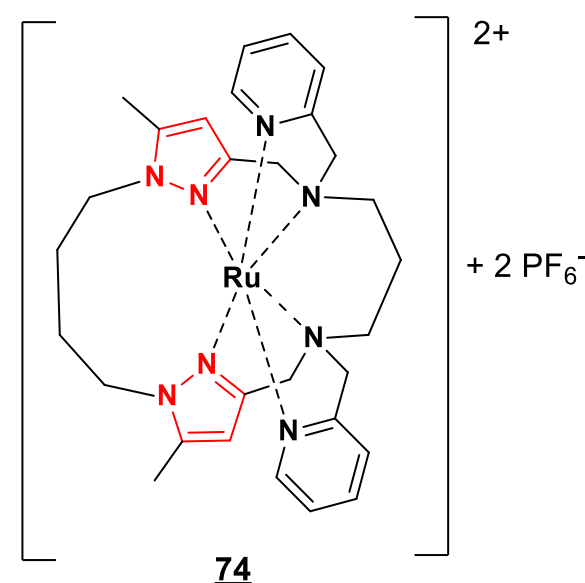

Figure 30. Structure of compound 7 [72]. 


\section{Conclusion}

The inhibitory effect of pyrazole derivatives on the corrosion of different metals in $\mathrm{HCl}$, $\mathrm{H}_{2} \mathrm{SO}_{4}, \mathrm{H}_{3} \mathrm{PO}_{4}$ and $\mathrm{NaCl}$ medium was studied by weight loss, electrochemical polarization and impedance studies. The maximum inhibition efficiency depends on the increase of the inhibitor concentration and the temperature. The inhibition effect is caused by geometrically blocking the surface of metal by adsorbed inhibitive molecules, which follow Langmuir isotherm model. The quantum calculations DFT and theoretically studies were in good correlation with experimental ones.

\section{Acknowledgments}

The authors would thank all the professor's participants in these papers a long these years 1996-2020, Professors Abdelkrim Ramdani, Sekkou Kertit, Sghir El Kadiri, Taibi Ben Hadda.

\section{References}

1. H. Jun, Y. Ye-Gao, W. Tao, L. Dan and H. Xiao-Chun, Design and solvothermal synthesis of luminescent copper(I)-pyrazolate coordination oligomer and polymer frameworks, Chem. Commun., 2006, 27, 2845-2847. doi: 10.1039/B601009A

2. M. El Boutaybi, A. Taleb, R. Touzani and Z. Bahari, Importance of pyrazole carboxylic acid in MOFs preparation, Arab. J. Chem. Environ. Res., 2020, 7, no. 1, 1-11.

3. S. Tighadouini, S. Radi, A New Silica Hybrid Material Based Adsorbent with NCCBipyrazolic Tripodal Receptor for Environmental Purpose, Arab. J. Chem. Environ. Res., 2015, 02, 1-14.

4. E.B. Rusanov, V.V. Ponomarova, V.V. Komarchuk, H. Stoeckli-Evans, E. FernandezIbanez, F. Stoeckli, J. Sieler and K.V. Domasevitch, A topology paradigm for metalorganic zeolites, Angew. Chem., Int. Ed., 2003, 42, no. 22, 2499-2501. doi: 10.1002/anie.200250534

5. I. Boldog, E.B. Rusanov, J. Sieler, S. Blaurock and K.V. Domasevitch, Construction of extended networks with a trimeric pyrazole synthon, Chem. Commun., 2003, 6, 740741. doi: $10.1039 / \mathrm{b} 212540 \mathrm{~d}$

6. I.Boldog, E.B. Rusanov, A.N. Chernega, J. Sieler and K.V. Domasevitch, Coordination polymers of $\mathrm{Co}^{\mathrm{II}}$ and 3,3',5,5'-tetramethyl-4,4'-bipyrazolyl: a novel metal-organic threedimensional network with four-coordinated planar vertices, J. Chem. Soc., Dalton Trans., 2001, 6, 893-897. doi: 10.1039/b007183h

7. V. Berdini, M.A. O’Brien, M.G. Carr, N.G.M. Davies, A.L. Gill, E.F. Navarro, S. Howard, G. Trewartha, A.J. Woodhead, A.J.-A. Woolford and P.G. Wyatt, Preparation of pyrazole derivatives that modulate the activity of CDK, GSK and aurora kinases, PCT Int. Appl., 2006, WO/2006/070198. 
8. D. Kumar and S.P. Singh, The structure of the products resulting from dehydroacetic acid and hydrazines, J. Ind. Chem. Soc., 2006, 83, no. 5, 419-426. doi: 10.1002/chin.200704242

9. A.M.K. Pennel, J.B. Aggen, J.J.K. Wright, S. Sen, B.E. Mcmaster, D.J. Dairaghi, W. Chen and P. Zhang, Preparation of substituted piperazine derivatives as CCR1 receptor antagonists, U.S. Pat. Appl. Publ., 2006, US/2006/106218.

10. A.M.K. Pennell, J.B. Aggen, J.J.K. Wright, S. Sen, B.E. Mcmaster, D.J. Dairaghi, $\mathrm{W}$. Chen and P. Zhang, Preparation of substituted piperazine derivatives as CCR1 receptor antagonists, PCT Int. Appl., 2005, WO/2005/056015.

11. N.D.P. Cosford, C. Chen, B.W. Eastman, H. Dehua, B. Munoz, P. Prasit and N.D. Smith, Preparation of heteroaryl substituted pyrazole modulators of metabotropic glutamate receptor-5, PCT Int. Appl., 2003, WO/2003/051833.

12. L.-D. Cantin, X. Ma, C. Akuche and S.X. Liang, Preparation of anilino-heteroarylpyrazoles useful for the treatment of diabetes, PCT Int. Appl., 2005, WO/2005/112923.

13. V.B. Halnor, N.S. Joshi, B.K. Karale and C.H. Gill, Synthesis and biological activities of some pyrazolines, Ind. J. Heter. Chem., 2005, 14, no. 4, 371-372.

14. Z. Zhang, T.S. Daynard, M.A. Chafeev, S. Wang, G.B. Chopiu and S.V. Sviridov, Preparation of hydrazonodiaminopyrazoles as integrin-linked kinase inhibitors with antiproliferative activity, PCT Int. Appl., 2003, WO/2003/045379.

15. H. Ohara, T. Igarashi, K. Sakurai and T. Oshii, Preparation of bipyrazole derivatives and pharmaceuticals or analytical reagents containing them, Jpn. Kokai Tokkyo Koho, 1998.

16. H. Franke, U. Hartfiel, M. Ganzer, E. Richter and J. Bohner, Preparation of Nbipyrazolylformamides as herbicides, Ger. Offen., 1998.

17. A. Katsumata, Y. Tamada, T. Kudou, M. Saeki and T. Yano, Preparation of bipyrazole derivatives as herbicides, PCT Int. Appl., 2005, WO/2005/085205.

18. F. Maurer, R. Fuchs, C. Erdelen and A. Turberg, Preparation of 1,4'-bi-1H-pyrazoles for use as pesticidal coating material agents, PCT Int. Appl., 2003, WO/2003/059887.

19. R. Yamamoto, Preparation of bipyrazole compounds by decomposition of nickel complexes of bipyridine and halopyrazoles, Jpn. Kokai Tokkyo Koho, 1999.

20. F. Malek, A. Ramdani, I. Zidane and S. Radi, Synthesis and transport abilities of new membrane materials incorporating mono- and bi-pyrazole compounds, Eur. Polymer J., 2005, 41, no. 4, 817-821. doi: 10.1016/j.eurpolymj.2004.11.003

21. F. Malek, A. Ramdani and S. Radi, Pyrazolic tripods synthesis and cation binding properties, J. Chem. Res., 2004, 9, 640-641. doi: 10.3184/0308234042430458

22. S. Radi, A. Ramdani, Y. Lekchiri, M. Morcellet, G. Crini and L. Janus, New tetrapyrazolic macrocycle. Synthesis and preliminary use in metal ion extraction. Tetrahedron, 2004, 60, no. 4, 939-942. doi: 10.1016/j.tet.2003.11.029

23. P. Ballesteros Garcia and S. Cerdan Garcia-Esteller, Preparation of novel ligands for Gd(III), with bi- and bis-azolic structures, useful in imaging diagnosis, and stability and magnetic relaxivity of their complexes, PCT Int. Appl., 2002, WO/2002/059097. 
24. H. Jones, M. Newell, C. Metcalfe, S.E. Spey, H. Adams, J.A. Thomas, Deprotonation of a ruthenium (II) complex incorporating a bipyrazole ligand leading to optical and electrochemical switching, Inorg. Chem. Commun., 2001, 4, no. 9, 475-477. doi: 10.1016/S1387-7003(01)00228-3

25. C.Verma, V.S. Saji, M.A. Quraishi and E.E. Ebenso, Pyrazole derivatives as environmental benign acid corrosion inhibitors for mild steel: Experimental and computational studies, J. Mol. Liq., 2020, 298, 111943. doi: $\underline{10.1016 / \text { j.molliq.2019.111943 }}$

26. C.E.B. Maia, G.A. Romeiro, M.C.C. Veloso, B.S. Peixoto and R.V. Rodrigues, Investigation of 1-(2-benzothiazolyl)-3-methylpyrazol-5-one as a corrosion inhibitor for carbon steel in $1 \mathrm{~mol} / \mathrm{L}$ hydrochloric acid, Rev. Virtual Quim., 2018, 10, no. 1,102-115. doi: $\underline{10.21577 / 1984-6835.20180010}$

27. F. El Hajjaji, F. Abrigach, O. Hamed, M.V.M. de Yuso and M. Algarra, Corrosion resistance of mild steel coated with organic material containing pyrazol moiety, Coatings, 2018, 8, no. 10, 330.

28. Y. Kaddouri, A. Takfaoui, F. Abrigach, B. Hammouti, R. Touzani and H. Sdassi, Tridentate pyrazole ligands: Synthesis, characterization and corrosion inhibition properties with theoretical investigations, J. Mater. Environ. Sci., 2017, 8, no. 3, 845-856.

29. L. El Hattabi, S. Echihi, M. El Fal, E.M. Essassi and M. Tabyaoui, Electrochemical and quantum chemical study of 1-ethyl-1H-pyrazolo[3,4-d] pyrimidine-4(5H)-thione as corrosion inhibitor for mild steel in $\mathrm{HCl}$ solution, J. Mater. Environ. Sci., 2017, 8, no. 7, 2428-2441.

30. J. Bouhoud, M. El Fal, Y. Ramli, A. Bellaouchou and E.M. Essassi, Electrochemical and theoretical studies of adsorption and corrosion inhibition of 1-methyl-4-methylsulfanyl$1 \mathrm{H}$-pyrazolo[3,4-d]pyrimidine on mild steel in acidic solution, J. Mater. Environ. Sci., 2017, 8, no. 6, 1935-1947. doi: 10.26872/jmes.2018.9.2.49

31. Y.E. Louadi, F. Abrigach, A. Bouyanzer, A. Zarrouk, B. Hammouti, Theoretical and experimental studies on the corrosion inhibition potentials of two tetrakis pyrazole derivatives for mild steel in $1.0 \mathrm{M} \mathrm{HCl}$, Port. Electrochim. Acta, 2017, 35, no. 3, 159178. doi: $10.4152 /$ pea. 201703159

32. H. Zarrok, A. Zarrouk, R. Salghi, R. Touzani and H. Oudda, Corrosion and corrosion inhibition of carbon steel in hydrochloric acid solutions by 2-[bis-(3,5-dimethyl-pyrazol1-ylmethyl)-amino]-3-hydroxy-butyric acid, Der Phar. Let., 2013, 5, no. (3), 327-335.

33. M. Bouklah, Y. Karzazi, M. Kaddouri, M.E. Belghiti, Y. Toubi, B. Hammouti, A. Aouniti, S. Radi and K. Emran, Thermodynamic characterization of metal dissolution and inhibitor adsorption processes in mild steel/new bipyrazole derivatives/hydrochloric acid system, Asian J. Chem., 2017, 29, no. 8, 1827-1838.

34. H. Ju, J. Chen, C. Sun and Y. Li, Quantum chemical studies on some new bipyrazole derivatives as corrosion inhibitors for steel materials, Anti-Corrosion Meth. Mater., 2016, 63, no. 3, 231-235. doi: 10.1108/ACMM-11-2015-1615 
35. I. El Ouali， A. Chetouani，B. Hammouti，A. Aouniti， R. Touzani， S. El Kadiri and S. Nlate, Thermodynamic study and characterization by electrochemical technique of pyrazole derivatives as corrosion inhibitors for C38 steel in molar hydrochloric acid, Port. Electrochim. Acta, 2013, 31,no. 2, 53-78. doi: 10.4152/pea.201302053

36. M. Bouklah, M. Kaddouri, Y. Toubi, B. Hammouti, S. Radi and E.E. Ebenso, Corrosion inhibition of steel in hydrochloric acid solution by new $N, N^{\prime}$-bipyrazole piperazine derivatives, Inter. J. Electrochem. Sci., 2013, 8, no. 5, 7437-7454.

37. H. Zarrok， S.S. Al-Deyab， A. Zarrouk， R. Salghi， B. Hammouti， H. Oudda, M. Bouachrine and F. Bentiss, Thermodynamic characterization and density functional theory investigation of $1,1^{\prime}, 5,5^{\prime}$-tetramethyl-1H,1'H-3,3'-bipyrazole as corrosion inhibitor of C38 steel corrosion in HCl, Inter. J. Electrochem. Sci., 2012, 7, no. 5, 4047-4063.

38. H. Zarrok, H. Oudda, A. El Midaoui, A. Zarrouk, B. Hammouti, M. Ebn Touhami, A. Attayibat, S. Radi and R. Touzani, Some new bipyrazole derivatives as corrosion inhibitors for C38 steel in acidic medium, Res. Chem. Intermed., 2012, 38, no. 8, 20512063. doi: $10.1007 / \mathrm{s} 11164-012-0525-\mathrm{x}$

39. H. Bendaha, A. Zarrouk, A. Aouniti, B. Hammouti, S. El Kadiri, R. Salghi and R. Touzani, Adsorption and corrosion inhibitive properties of some tripodal pyrazolic compounds on mild steel in hydrochloric acid systems, Phys. Chem. News, 2012, 64, 95-103. doi: 10.4028/www.scientific.net/AMR.989-994.536

40. N. Boussalah, S. Ghalem, S. El Kadiri, B. Hammouti, R. Touzani, Theoretical study of the corrosion inhibition of some bipyrazolic derivatives: a conceptual DFT investigation, Res. Chem. Intermed., 2012, 38, no. 8, 2009-2023. doi: 10.1007/s11164-012-0522-0

41. K. Laarej, M. Bouachrine, S. Radi, S. Kertit and B. Hammouti, Quantum chemical studies on the inhibiting effect of bipyrazoles on steel corrosion in $\mathrm{HCl}$, E-J. Chem., 2010, 7, no. 2, 419-424. doi: $10.1155 / 2010 / 273206$

42. K. Tebbji, H. Oudda, B. Hammouti, M. Benkaddour, S.S. Al-Deyab, A. Aouniti, S. Radi and A. Ramdani, The effect of 1',3,5,5'-tetramethyl-1'H-1,3'-bipyrazole on the corrosion of steel in 1.0 M hydrochloric acid, Res. Chem. Intermed., 2011, 37, no. 8, 985-1007.

43. K. Tebbji, A. Aouniti, A. Attayibat, B. Hammouti, H. Oudda, M. Benkaddour, S. Radi and A. Nahle, A Inhibition efficiency of two bipyrazole derivatives on steel corrosion in hydrochloric acid media, Ind. J. Chem. Tech., 2011, 18, no. 3, 244-253.

44. A. Attayibat, R. Touzani, S. Radi, S. El Kadiri, S. Sari, I. Abdelli and S. Ghalem, Quantum chemical studies on $N$-donors based-pyrazole compounds as corrosion inhibitors for steel in acidic media, Asian J. Chem., 2009, 21, no. 1, 105-112.

45. H. Wang, X. Wang, H. Wang, L. Wang and A. Liu, DFT study of new bipyrazole derivatives and their potential activity as corrosion inhibitors, J. Mol. Model., 2007, 13, no. 1, 147-153. doi: $10.1007 / \mathrm{s} 00894-006-0135-\mathrm{X}$

46. K. Tebbji, A. Aouniti, M. Benkaddour, H. Oudda, I. Bouabdallah, B. Hammouti, A. Ramdani, New bipyrazolic derivatives as corrosion inhibitors of steel in $1 \mathrm{M} \mathrm{HCl}$, Prog. Org. Coatings, 2005, 54, no. 3, 170-174. doi: 10.1016/j.porgcoat.2005.06.001 
47. K. Tebbji, I. Bouabdellah, A. Aouniti, B. Hammouti, H. Oudda, M. Benkaddour and A. Ramdani, N-benzyl-N,N-bis[(3,5-dimethyl-1H-pyrazol-1-yl)methyl]amine as corrosion inhibitor of steel in $1 \mathrm{M} \mathrm{HCl}$, Mater. Letters, 2007, 61, no. 3, 799-804.

48. M. Benabdellah, R. Touzani, A. Aouniti, A. Dafali, S. El Kadiri, B. Hammouti and M. Benkaddour, Inhibitive action of some bipyrazolic compounds on the corrosion of steel in $1 \mathrm{M} \mathrm{HCl}$. Part 1. Electrochemical study, Mater. Chem. Phys., 2007, 105, no. $2-$ 3, 373-379. doi: 10.1016/j.matchemphys.2007.05.001

49. M. Bouklah, A. Attayibat, B. Hammouti, A. Ramdani, S. Radi and M. Benkaddour, Pyridine-pyrazole compound as inhibitor for steel in $1 \mathrm{M} \mathrm{HCl,} \mathrm{Appl.} \mathrm{Surf.} \mathrm{Sci.,} \mathrm{2005,}$ 240, no. 1-4, 341-348. doi: 10.1016/j.apsusc.2004.07.001

50. K. Tebbji， B. Hammouti, H. Oudda, A. Ramdani and M. Benkadour, The inhibitive effect of bipyrazolic derivatives on the corrosion of steel in hydrochloric acid solution, Appl. Surf. Sci., 2005, 252, no. 5, 1378-1385. doi: 10.1016/j.apsusc.2005.02.097

51. M. Bouklah, B. Hammouti, M. Benkaddour, A. Attayibat and S. Radi, Corrosion inhibition of steel in hydrochloric acid solution by new bipyrazole derivatives, Pigm. Resin Tech., 2005, 34, no. 4, 197-202. doi: 10.1108/03699420510609088

52. K. Tebbji， H. Oudda， B. Hammouti, M. Benkaddour, M. El Kodadi, F. Malek and A. Ramdani, Inhibitive action of two bipyrazolic isomers towards corrosion of steel in $1 \mathrm{M} \mathrm{HCl}$ solution, Appl. Surf. Sci., 2005, 241, no. 3-4, 326-334. doi: 10.1016/j.apsusc.2004.08.033

53. A. Chetouani, B. Hammouti, T. Ben Hadda and M. Daoudi, Inhibitive action of bipyrazolic type organic compounds towards corrosion of pure iron in acidic media, Appl. Surf. Sci., 2005, 249, no. 1-4, 375-385. doi: 10.1016/j.apsusc.2004.12.034

54. M. Elayyachy, M. El Kodadi, A. Aouniti, A. Ramdani, B. Hammouti, F. Malek and A. El Idrissi, New bipyrazole derivatives as corrosion inhibitors for steel in hydrochloric acid solutions, Mater. Chem. Phys., 2005, 93, no. 2-3, 281-285. doi: 10.1016/j.matchemphys.2005.03.059

55. K. Tebbji, H. Oudda, B. Hammouti, M. Benkaddour, M. El Kodadi and A. Ramdani, Inhibition effect of two organic compounds pyridine-pyrazole type in acidic corrosion of steel, Colloids Surf., A., 2005, 259, no. 1-3, 143-149. doi: 10.1016/j.colsurfa.2005.02.030

56. M. Elayyachy, M. El Kodadi, B. Hammouti, A. Ramdani and A. El Idrissi, Characterization of a new tripyrazole derivative as inhibitor for the steel corrosion in acid solution, Pigm. Resin Tech., 2004, 33, no. 6, 375-379. doi: 10.1108/03699420410568409

57. A. Yahyi, B. Hammouti, A. Aouniti, S. Kertit and A. Ramdani, Synthesis and application of o-acrylate dipyrazole methane as corrosion inhibitors of pure iron in molar hydrochloric acid solution, Trans. SAEST, 2004, 39, 5-8.

58. R. Salghi, L. Bazzi, B. Hammouti and S. Kertit, Electrochemical behavior of aluminum alloy 6063 in deaerated carbonate solution in presence of pyrazolic compounds, Bull. Electrochem., 2000, 16, no. 6, 272-276. 
59. F. Touhami, A. Aouniti, Y. Abed, B. Hammouti, S. Kertit and A. Ramdani, New pyrazolic compounds as corrosion inhibitors for Iron Armco in $\mathrm{HCl}$ media, Bull. Electrochem., 2000, 16, no. 6, 245-249.

60. F. Touhami, A. Aouniti, Y. Abed, B. Hammouti, S. Kertit, A. Ramdani and K. Elkacemi, Corrosion inhibition of Armco iron in $1 \mathrm{M} \mathrm{HCl}$ media by new bipyrazolic derivatives, Cor. Sci., 2000, 42, no. 6, 929-940. doi: 10.1016/S0010-938X(99)00123-7

61. F. Touhami, B. Hammouti, A. Aouniti and S. Kertit, A new bipyrazolic compound as corrosion inhibitor of Armco iron in $1 \mathrm{M} \mathrm{HCl}$ medium, Ann. Chim., 1999, 24, no. 8, 581-586. https://doi.org/10.1016/S0151-9107(00)86628-3

62. B. Hammouti, R. Salghi and S. Kertit, Electrochemical behavior of lead in $0.3 \mathrm{M} \mathrm{HCl}$ in presence of pyrazolic compounds, J. Electrochem. Soc. Ind., 1998, 47, no. 1, 31-34.

63. A. Aouniti, B. Hammouti, M. Brighli, S. Kertit, F. Berhili, S. El Kadiri and A. Ramdani, Inhibition of the acid corrosion of iron with new pyrazole derivatives, J. Chim. Phys. Phys.-Chim. Biol., 1996, 93, no. 7-8, 1262-1280. doi: 10.1051/jcp/1996931262

64. A. El Ouafi, B. Hammouti, H. Oudda, S. Kertit, R. Touzani and A. Ramdani, New bipyrazole derivatives as effective inhibitors for the corrosion of mild steel in $1 \mathrm{M} \mathrm{HCl}$ medium, Anti-Cor. Meth. Mater., 2002, 49, no. 3, 199-204. doi: $10.1108 / 00035590210426463$

65. R. Salghi, L. Bazzi, B. Hammouti, E. Zine, S. Kertit, S. El Issami and E. Ait. Addi, Corrosion inhibition of lead in $0.3 \mathrm{M} \mathrm{HCl}$ media by bipyrazolic compounds, Bull. Electrochem., 2001, 17, no. 9, 429-432.

66. S. El Arouji, K. Alaoui Ismaili, A. Zerrouki, A. Aouniti, B. Hammouti, Inhibition effects of a new syntheses pyrazole derivative on the corrosion of mild steel in sulfuric acid solution, Der Phar. Chem., 2015, 7, no. 10, 67-76.

67. S. El Arouji, K. Alaoui Ismaili, A. Zerrouki, A. Aouniti, B. Hammouti, Experimental and theoretical study on the corrosion inhibition of mild steel by ethyl 1-(((4-acetylphenyl)((3-(ethoxycarbonyl)-1H-pyrazol-1-yl)methyl)amino)methyl)-5-methyl-1H-

pyrazole-3-carboxylate in sulfuric acid solution, Der Phar. Chem., 2015, 7, no. 10, 23-33.

68. D. Hmamou, R. Salghi, A. Zarrouk, H. Zarrok, R. Touzani, B. Hammouti and A. El Assyry, Investigation of corrosion inhibition of carbon steel in $0.5 \mathrm{M} \mathrm{H}_{2} \mathrm{SO}_{4}$ by new bipyrazole derivative using experimental and theoretical approaches, J. Environ. Chem. Engin., 2015, 3, no. 3, 2031-2041. doi: 10.1155/2014/945645

69. A. Ouchrif, M. Zegmout, B. Hammouti, S. El Kadiri and A. Ramdani, 1,3-Bis(3hyroxymethyl-5-methyl-1-pyrazole) propane as corrosion inhibitor for steel in $0.5 \mathrm{M}$ $\mathrm{H}_{2} \mathrm{SO}_{4}$ solution, Appl. Surf. Sci., 2005, 252, no. 2, 339-344. doi: 10.1016/j.apsusc.2005.01.005

70. B. Hammouti, A. Dafali, R. Touzani and M. Bouachrine, Inhibition of copper corrosion by bipyrazole compound in aerated $3 \% \mathrm{NaCl}$, J. Saudi Chem. Soc., 2012, 16, no. 4, 413418. doi: 10.1016/j.jscs.2011.02.009

71. A. Dafali, B. Hammouti, R. Touzani, S. Kertit, A. Ramdani and K. El Kacemi, Corrosion inhibition of copper in 3 per cent $\mathrm{NaCl}$ solution by new bipyrazolic 
derivatives, Anti-Corros. Meth. Mater., 2002, 49, no. 2, 96-104. doi: $10.1108 / 00035590210419335$

72. M. Benabdellah, R. Touzani, A. Dafali, B. Hammouti and S. El Kadiri, Rutheniumligand complex, an efficient inhibitor of steel corrosion in $\mathrm{H}_{3} \mathrm{PO}_{4}$ media, Mater. Let., 2007, 61, no. 4-5, 1197-1204. doi: 10.1016/j.matlet.2006.06.082

73. S. El Arrouji, K. Karrouchi, A. Berisha, K. Ismaily Alaoui, I. Warad, Z. Rais, S. Radi, M. Taleb, M. Ansar and A. Zarrouk, New pyrazole derivatives as effective corrosion inhibitors on steel-electrolyte interface in $1 \mathrm{M} \mathrm{HCl}$ : Electrochemical, surface morphological (SEM) and computational analysis, Colloids Surf., A, 2020, 604, 125325. doi: $10.1016 /$ j.colsurfa.2020.125325

74. A. Titi, T. Shiga, H. Oshio, R. Touzani, B. Hammouti, M. Mouslim and I. Warad, Synthesis of novel $\mathrm{Cl}_{2} \mathrm{Co}_{4} \mathrm{~L}_{6}$ cluster using 1-hydroxymethyl-3,5-dimethylpyrazole (LH) ligand: Crystal structure, spectral, thermal, Hirschfeld surface analysis and catalytic oxidation evaluation, J.Mol. Struct., 2020, 1199, $126995 . \quad$ doi: 10.1016/j.molstruc.2019.126995

75. N. Arrousse, El. Mabrouk, B. Hammouti, F. El Hajjaji, Z. Rais and M. Taleb, Synthesis, characterization, anti-corrosion behavior and theoretical study of the new organic dye: 3-oxo-3H-spiro[isobenzofuran-1,9'-xanthene]-3',6'-diyl bis(3-methylbenzenesulfonate), Int. J. Corros. Scale Inhib., 2020, 9, no. 2, 661-687. doi: 10.17675/2305-6894-2020-9$2-18$

76. M. Bouklah, W. Daoudi, B. Hammouti，A. Aouniti， R. Salghi， Inhibitor adsorption processes in mild steel/new bipyrazole derivatives/hydrochloric acid system, Mater. Today: Proc., 2020, 27, 3209-3216. doi: 10.1016/j.matpr.2020.04.507

77. M. El Azzouzi, A. Aouniti, M. El Massaoudi, S. Radi, B. Hammouti, M.A. Quraishi, H. Bendaif and Y.El Ouadi, Inhibition effect of 1,1'-(pyridine-2,6-dihylbis(methylene))bis(5-methyl-1H-pyrazole-3-carboxylic acid) on the corrosion of mild steel in 1 M HCl. Part A: Experimental study, Int. J. Corros. Scale Inhib., 2017, 6, no. 4, 463475. doi: $10.17675 / 2305-6894-2017-6-4-6$

78. M. Lamsayah, A. Takfaoui, A. Mouadili, M. Haibach, A.J. Nawara-Hultzsch, T.J. Emge and R. Touzani, Pyrazole and quinoxaline: synthesis and $\mathrm{X}$-ray structural characterization of new tridentate $(\mathrm{N}, \mathrm{N}, \mathrm{N})$ and bidentate $(\mathrm{N}, \mathrm{N}$ or $\mathrm{N}, \mathrm{O})$ ligands, Mor. $J$. Chem. 2014, 2, no. 3, 199-210. doi: 10.48317/IMIST.PRSM/morjchem-v2i3.1961

79. S.A. Mrani, S. El Arrouji, K. Karrouchi, F. El Hajjaji, K.I. Alaoui, Z. Rais and M. Taleb, Inhibitory performance of some pyrazole derivatives against corrosion of mild steel in $1.0 \mathrm{M} \mathrm{HCl}$ : Electrochemical, MEB and theoretical studies, Int. J. Corros. Scale Inhib., 2018, 7, no. 4, 542-569. doi: $10.17675 / 2305-6894-2018-7-4-5$

80. H. Elmsellem, T. Harit, A. Aouniti, F. Maek, A. Riahi, A. Chetouani and B. Hammouti, Adsorption properties and inhibition of mild steel corrosion in $1 \mathrm{M} \mathrm{HCl}$ solution by some bipyrazolic derivatives: Experimental and theoretical investigations, Prot. Met. Phys. Chem. Surf., 2015, 51, no. 5, 873-884. 